\title{
THE POLITICS OF LIMITATION OF CLAIMS IN POLAND: POST-COMMUNIST IDEOLOGY, NEOLIBERALISM AND THE PLIGHT OF UNINFORMED DEBTORS
}

\begin{abstract}
The text will present arguments raised by the supporters of two different positions regarding the manner of taking into account the expiry of the limitation period, namely those that are supposed to speak in favor of taking this circumstance by the courts ex officio, and those which prevail to take it into account only in the event of raising the plea of limitation by the one against whom the claim is due. Against this background, a polemical analysis will be made with these arguments, including inquiries about interests of which entities or social groups are implemented and protected for each of these solutions. It will be shown that some of the arguments put forward actually emphasize that the institution of limitation is to serve not so much as a party involved in a given claim (creditors or debtors), but rather institutions of the judiciary. It will also be shown that the solution currently in force in Polish civil law, within which the taking into account of the fact that a given claim is time-barred is possible only if the one against whom the claim is entitled raises the relevant claim of limitation, in fact prefers only the more affluent and better educated social strata, deepening the social exclusion of those who, due to, for example, worse property status, do not have the necessary knowledge, nor can afford to take advantage of legal aid. The latter, in effect, often do not plead the expiration of limitation period, because they do not know that they are entitled to it (in general, or are unable to assess when the claim became due, at which point the limitation period began or has ended). Polish civil law is a good example here for considering, firstly, that in the 20th century the regulations concerning the limitation of claims were changed several times, and each time a discussion on how to consider the expiry of the limitation period came to life (which provides rich argumentation with which one can confront) and also because historical and political entanglements play a significant role here. Namely, the text will show that the main resistance against taking into account the expiration of limitation period ex officio (which is a solution that protects the poorer people who can not afford legal assistance) is due to the fact that this solution, which was in force in the original version of the current Polish Civil Code, was modeled on the solutions of Soviet law. This means that after the political change in Poland in 1989, it was automatically attempted to eliminate it, and replace it with a solution used in European countries, where only if the one against whom the claim is entitled raises the relevant claim of limitation, even without any reflection on the substantive legitimacy of such a change and without analyzing the practical social effects of a solution, within which the expiry of the limitation period only is taking into account on when relevant plea is raised, not ex officio.

Immersion of considerations in the realities of Polish law will also allow to show interests that have recently clashed on the occasion of the regulation of electronic writ-of-payment proceedings. In this example, it will be shown that despite the legislator making certain facade measures to
\end{abstract}

* University of Wrocław, Faculty of Law, Administration and Economics, Civil and Private International Law Unit; legal counsel OIRP Wrocław, joanna.kuzmicka-sulikowska@uwr.edu.pl 
protect the interests of people with less legal awareness and poorer, who can not afford to get help from a lawyer, in fact, many gates have been left, which question the reality of striving for such protection, because they allow to sue for the claim after the expiration of the limitation period in this proceeding.

In this context, the latest change in Polish civil law in this area was also discussed, that is, the Act of April 13, 2018. On the basis of this Act, there has been a return to taking into account the expiration of the limitation period ex officio, but only if the entrepreneur sue the consumer. In the remaining scope, a solution was left within which the expiry of the limitation period is taking into account only when relevant plea is raised.

Keywords: claims, limitation period, taking the expiry of the limitation period into account, polish civil law, political and legal changes.

\section{INTRODUCTORY REMARKS ON THE SUBJECT OF LIMITATION OF CLAIMS}

The institution of limitation of claims gives rise to often fierce and incessant debate, to a degree greater than many other such issues. This should come as no surprise considering the fact that, for obvious reasons, it can be questioned on moral and ethical grounds. Indeed, limitation of claims in the civil law is a boon to the unreliable debtor, giving him the opportunity to avoid a debt which he failed to repay in a timely manner (which, in a general social sense, does not provide a particularly strong incentive to take care of one's obligations in time). In turn, limitations on the criminality of an act or enforcement of punishment against an offender allow a criminal to avoid the consequences of his actions (excepting pangs of conscience, to the extent they are felt), while limitations in tax law leads to reduced revenue in the budget of the State Treasury and local self-government units, and thus the pool of funds earmarked for projects that are intended to serve all of society (nota bene those members of society which have properly and in a timely fashion paid the necessary taxes can feel harmed as the indirect financers of investments designed to satisfy the needs of those who have been "released" from the obligation to pay taxes after a period of time). Attitudes in society to regulations on limitation of claims are very diverse. The very same people who press for justice to be meted out to the perpetrator of a crime even when discovered after many years are as taxpayers prone to supporting the expiration of the duty to pay taxes if they are not collected within a defined period of time. Indeed, the position of a given individual on that issue can change depending on the particular situation he finds himself in - if he is in debt to someone, and his financial situation is precarious, he can count on limitation of that claim as a means of extricating himself from the situation; however, if he is in possession of a claim towards someone else (such as for work performed), the idea that his debtor may be able to get out of that obligation by invoking the defence of limitation will seem an obvious injustice and irrationality of the legal system. 
In the light of the foregoing, it should not come as a surprise that a great deal of effort has been expended in legal scholarship to convince the addressee of legal norms as to the necessity and the legitimacy of the institution of limitation. In Polish conditions this is all the more necessary when considering the jurisprudence of the Constitutional Tribunal holds that the Constitution of Poland does not establish limitation of claims as a subjective right, from which it follows that a given individual's anticipation of the limitation of a claim does not constitute a legally protected expectative, as the rule should be that a given individual performs the duties incumbent on him rather than wait for the limitation of a claim. ${ }^{1}$ The Constitutional Tribunal consistently holds that the Constitution of Poland "does not formulate a general statute of limitations that would demand elaboration and concretization within particular branches of the law", ${ }^{2}$ and "limitation of claims is not a constitutionally established subjective right, and even if the legislator did not create such an institution it would be wrong to claim that some constitutionally guaranteed rights or freedoms had been violated as a result".

It should therefore come as no surprise that in the legal literature we may find examples of tremendous efforts to find the greatest number of justifications for the existence of legislation instituting limitations on claims. In the past I have examined this issue in more detail, exploring the effort made by Polish scholars of the civil law to convince readers of the necessity of regulations on limitations of claims. These deliberations led to a range of findings, including two of significance to the issue at hand. First, analysis of the content and the style of those statements led me to the conclusion that they are of a highly persuasive nature. In spite of the authors writing of the goals, tasks, effects, or real results of the impact of legal provisions introducing limitations on claims, it should be observed that none of them either invoked or themselves carried out empirical studies on the social effects of such laws. Thus we may treat such statements at best as the musings of particular authors about their convictions as to what those effects should be. They are always presented in a positive manner (the assumed functions of limitation), which is evidently designed to convince others to the functioning of the mechanism of limitations on claims (for more see: Kuźmicka-Sulikowska 2015, 93-118). Secondly, however, my research led me to an understanding of the wealth of justifications submitted as motives in support of norms implementing

\footnotetext{
${ }^{1}$ Judgment of the Polish Constitutional Tribunal of 25 May 2004, SK 44/03, Z.U. 2004/5A/46; judgment of the Polish Constitutional Tribunal of 19 June 2012, P 41/10, Z.U. 2012/6A/65; judgment of the Polish Constitutional Tribunal of 8 October 2013, SK 40/12, Z.U. 2013/7A/97; judgment of the Polish Constitutional Tribunal of 17 July 2012, P 30/11, Z.U. 2012/7A/81. A similar position is taken by the Polish Supreme Court (see e.g. order of this court of 2 July 2002, II KK 143/02, Lex no. 55526).

2 Judgment of the Polish Constitutional Tribunal of 17 July 2012, P 30/11, Z.U. 2012/7A/81.

${ }^{3}$ Judgment of the Polish Constitutional Tribunal of 17 July 2012, P 30/11, Z.U. 2012/7A/81. Also: Judgment of the Polish Constitutional Tribunal of 8 October 2013, SK 40/12, Z.U. 2013/7A/97.
} 
limitations on claims. In this context we may cite such examples as: elimination of evidentiary difficulties, protection of the debtor's expectations, refusal of legal protection for a neglectful creditor who fails to pursue claims in a timely manner, punishment of a creditor for tardiness in pursuing claims without delay, and even the conclusion that failure by a debtor to pursue a claim after a certain time gives rise to the presumption that his real intention was to "forgive" the debt. Sometimes the argument is raised that limitations serve to petrify an existing state of affairs, to achieve certainty and clarity in civil law transactions, and also to avoid unintended crediting, to maintain financial discipline, to ensure public order, and to shape desirable social attitudes (see: Kuźmicka-Sulikowska 2015, 61-71 as well as the literature and case-law cited therein).

In light of the foregoing it should be observed that deciphering this nature of statements from legal scholars on the subject of limitations on the one hand, and the multiplicity of arguments invoked to convince others of the rationality of norms implementing limitations on the other hand, paradoxically attests to the doubtful axiological foundation on which the institution of limitations on claims rests. Something which is obviously necessary need not be justified with such fervour. As it is, the majority of arguments employed in support of limitations of claims, when examined more thoroughly, emerge as being tightly enmeshed among various competing interests. For example, one may indicate that this is true of the argument in favour of limitations that they allow courts to avoid problematic evidentiary proceedings which generate difficulties due to their being conducted years after the existence of a claim and its enforceability; at times the argument of preventing an excessive number of judicial procedures is also invoked. Authors advancing this perspective are doubtlessly concerned not only with relieving the burden on courts, but also on the budget, as litigation is certainly not "profitable" from the perspective of public finances (when taking into account e.g. remuneration for judges, court employees, charges for utilities, etc., only a portion of which is covered by court fees paid by the parties). What is particularly significant in the present context, this argument is also eagerly employed by courts in rulings addressing the issue of limitation of claims, where a clear concern is evident for their own comfort and for relieving themselves of the burden of difficult cases (it means years after the occurrence of the facts which they are supposed to assess), hidden under a seemingly neutral slogan of "caring for the correctness of judicial decisions". ${ }^{4}$ Firstly, however, in the present Polish reality this argument seems generally flawed - according to the provisions of the Code of Civil Procedure, the burden of proof rests primarily on the parties, ${ }^{5}$ and the trial is subject to the principle of adversarial procedure. Secondly, and of

${ }^{4}$ See e.g. judgment of the Polish Supreme Court of 10 January 2001, I CKN 988/00, Lex no. 171258 .

${ }^{5}$ Particularly in Art. 3 of the Code of Civil Procedure of 17 November 1964 (Dz.U. 2016, item 1822 with amendments). 
particular importance in the context of the deliberations being conducted here, by its nature, limitation of claims concerns both the creditor and debtor as well as the relation between them, in light of which statutory solutions which take into account the interests of a third party (courts) comes across as entirely unjustified, as that party is not impacted by the situation.

It is worth observing that a detailed analysis and polemic approach to the whole of the arguments raised in the literature and case-law justifying the institution of limitations of claims has led me to the conclusion in other writings devoted to that issue that the sole argument which endures - and that only partially - is the one which refers to certainty of law achieved due to limitation in the context of a particular claim (Kuźmicka-Sulikowska 2015, 71-93); yet here too with far-reaching reservations that this occurs only after the litigation has definitively concluded and a claim which has been ascertained with finality in a judgement is also subjected the statute of limitations, ${ }^{6}$ etc.

In this article, however, I would like to focus on the question of whether one of the solutions adopted in the Polish Civil Code - specifically, that concerning the manner of which the expiration of the limitation period is taken into consideration - serves the materialization of the one argument in favour of limitation that stands up in the face of the arguments against it, or perhaps is there an entirely different rationale behind that particular solution.

The Polish normative material supplies us with rich matter for consideration, as even over the last several dozen years the legal solutions applied in this area have undergone changes, and what follows, each such change opens the door to discussion of the material under consideration. What is more, the solution presently in effect was implemented in 1990, just one year after the historic events in Poland of 1989, which - as will be demonstrated - had a decisive effect on the adoption of the presently employed model of accounting for the expiration of the limitation period.

\section{A BRIEF HISTORICAL OVERVIEW OF SOLUTIONS IN THE POLISH LAW CONCERNING MANNERS OF TAKING INTO ACCOUNT THE EXPIRATION OF THE LIMITATION PERIOD}

To avoid reaching too far back into time, it is sufficient to point out that within the framework of legal solutions existing in the various post-partition legal regimes there were regulations in effect under which the circumstance that a limitation period of given claim pursued in court had expired could only be taken into account when set up as a defence. This construction remained in effect

${ }^{6}$ Under Art. $125 \S 1$ of the Polish Civil Code of 23 April 1964 (Dz.U. 2016, item 380 with amendments). 
until the adoption in 1933 of the Code of Obligations, ${ }^{7}$ where it was formulated in a negative manner, meaning (in Art. $273 \S 3$ ) as a prohibition on the court taking it into account on its own initiative, that is ex officio. Furthermore, in the legal literature it was pointed out that, as a consequence, it is impermissible for the court to ask a party if it renounces the right to set up the defence of expiration of the limitation period (Domański 1936, 919).

Similarly, under the 1950 General Provisions of the Civil Law ${ }^{8}$ limitation of a claim could only be taken into consideration by the court upon a relevant motion by the party against which the claim is demanded, that is, at petitionem. It is worth noting that this rule was not expressed in the 1950 regulations directly, but rather was interpreted from the entirety of their provisions, in particular Art. 106, $107 \S$ 1, and 115 (Gwiazdomorski 1955, 16; Gwiazdomorski 1968, 89).

The first deviations from the rule according to which expiration of a claim was only accepted upon a motion by the party against which the claim is demanded were introduced in the $1950 \mathrm{~s}$, when regulation went into effect introducing ex officio consideration of expiration of the limitation period in arbitration proceedings and proceedings concerning termination of a labour contract without notice. ${ }^{9}$

However, in the Civil Code adopted in $1964,{ }^{10}$ as concerns the manner of taking into consideration expiration of the limitation period for a claim being pursued, the general solution adopted was ex officio invocation subject to the reservation of accounting for the will of the party entitled to the defence, about which more will be said later on. Specifically, in respect of "socialist trade" (id est among entities of the socialized economy subject to state arbitration), a consequence of expiration of the limitation period was that the claim became unenforceable; the court took this into consideration ex officio and the parties had no way of influencing the court in this matter (Broniewicz 1965, 61). However, in relations among other entities, so-called "general trade", the court took the expiration of the limitation period into account ex officio, but the debtor could renounce the right to invoke the defence. Furthermore, the court could (under Art. $117 \S 3$ as in effect at the time) choose not to dismiss a suit for an claim despite the end of its limitation period on its own initiative, if the limitation period for that type of claim did not exceed three years, the delay in pursuing the claim was not excessive, and it was justified by extraordinary circumstances.

\footnotetext{
${ }^{7}$ Regulation of the President of the Republic of Poland of 27 October 1933 - Code of Obligations (Dz.U. 82, item 598 with amendments).

${ }^{8}$ The Act on General Provisions of the Civil Law of 18 July 1950 (Dz.U. 34, item 311).

${ }^{9}$ Cagara 1961, 767-768; Regulation of the Council of Ministers of 20 December 1952 on the organization of the state arbitration commission and mode of arbitration proceedings (Dz.U. 2, item 2).

${ }^{10}$ Civil Code of 23 April 1964 (Dz.U. 2016, item 380 with amendments).
} 
The causes for which the provisions of the Polish Civil Code establish ex officio consideration of limitation of claims have been identified in a range of factors. Alongside indicating their reflection of Soviet legislation (Szpunar 2002, 17; Szpunar 1980, 16), it has also been said that this solution protects respondents less capable of defending themselves or less aware of their rights who would on their own not set up the defence of limitation of claim (Szpunar 1974, 285). It would seem that of importance in this context is also the form of regulations then in effect concerning civil procedure - particularly that they imposed far-reaching limitations on the principle of disposability (Szpunar 1970, 16; Szpunar 1974, 285), and the efforts of some scholars, including in reference to the legislative process, to unify regulation concerning limitation and preclusionary deadlines (Dobrzański 1960, 814).

A sea change in the regulation addressing the issue at hand was brought about by the Act of 28 July 1990 amending the Civil Code, which added to the Code solutions which from then on allowed for expiration of the limitation period on a claim to be taken into consideration only when invoked ad petitionem of the party against which the claim is pursued.

These relatively frequent changes to regulations of the Polish Civil Law concerning the manner in which expiration of the limitation period is taken into account have in every case served as an excellent starting point for lively discussions on the shape of legislation addressing the issue, while particularly fierce conflicts arose (and continue to this day) around the question of whether the expiration of a limitation period of a claim pursued before a court (or other appropriate authority) should be taken into account ex officio, or rather only when a relevant motion is brought. This discussion can by no means be considered finished, as both approaches enjoy their supporters and detractors, and the potential for sudden change remains an open question in light of ongoing work on a new Civil Code. For this reason it is worth taking a closer look at the most important arguments given in favour of each solution.

\section{ARGUMENTS RAISED IN FAVOUR OF TAKING INTO ACCOUNT EXPIRATION OF THE LIMITATION PERIOD UPON A MOTION BY THE PARTY AGAINST WHICH THE CLAIM IS PURSUED (AD PETITIONEM)}

To convince observers of the legitimacy of taking into account expiration upon a motion invoking that defence, the argument usually presented is the "special nature of the institution of limitation of claims", which supposedly justifies leaving the decision to employ the defence of the limitation period in the hands of the party against which the claim is pursued. An example frequently given is that of a sued doctor who may not wish for the court to dismiss claims against him on grounds of the limitation period, but would prefer to resolve the matter on the merits and 
demonstrate that he did not make an error in the performance of his duties, was not at fault, and in that manner bring about dismissal of the action against him with a view to preventing his being found responsible (Gwiazdomorski 1955, 18; Szpunar 1980, 16; Wilejczyk 2014, 437).

It is also worth noticing that many of the arguments cited by supporters of consideration of limitation of claim by the court only upon a motion of the party against which the claim is pursued is of a defensive nature, id est it serves to refute the charges of that solution's weakness. For example, we may point out that opponents of taking into account limitation of claim ad petitionem point out that this may lead to court rulings contradicting the law, as well as discrepancies in the case-law involving different verdicts in similar factual situations. In response, authors supporting the solution of taking limitation of claim into account ad petitionem declare that this should not lead to fears as to the course and result of the trial; indeed, a respondent who does not invoke the defence of limitation of claim in spite of being entitled to do so is usually in possession of evidence that will allow the court to examine the substance of the action, leading as a rule to its dismissal. Therefore, the necessity of a motion invoking limitation of a claim by the party against which the claim is pursued will not, in the view of supporters of that construction, lead to any evidentiary difficulties for the parties and the court, nor will it generate the risk of cases being resolved in a manner that would contradict the law (Gwiazdomorski 1955, 18).

The situation is similar to that of the argument frequently invoked against taking into account limitation of claim ad petitionem that it is detrimental to people unfamiliar with the law and who are unable to afford an attorney. In response, supporters of the construction by which the court takes into account limitation of a claim only when it is set up as a defence by the party against which the claim is pursued, formulated the argument in the 1950s that this solution does not at all serve the interests of the "propertied classes", and does not damage the interests of workers and labouring peasants (to use the rhetoric employed at the time in the legal literature), as such a threat was perceived only in respect of the legislation in bourgeois states, but not in conjunction with the socialist model of civil procedure in effect at the time. It was pointed out that in the latter model, the active role of the court in determining objective truth was a guarantee of real equality of the parties. The court, through initiating the examination of evidence and determining the circumstances of the case by the same token protects the interests of the economically weaker side, shielding it from damage on account of ignorance of the law and lack of financial means to employ a professional attorney. What is more, it was demonstrated that these chances are all the more even when considering that in instructing a party appearing without an attorney, the court draws attention to the possibility of invoking the defence of limitation of the claim (Gwiazdomorski 1955, 46-47, 17-18). 
However, under the current regulations (id est those in effect since 1990, and from $9^{\text {th }}$ of July 2018 in with regard to claims other than those claimed by enterpreneurs from consumers) ${ }^{11}$ of the Polish Civil Code which establish the necessity of raising the defence of limitation by the party against which the claim is pursued, supports of this solution argue that it is identical with that adopted in the laws of Western states (Wójcik 1991, 48; Brzozowski 1992, 25-26). At times they also point to the "moral superiority" of such a measure, because it is precisely the feeling of morality (defined variously, for example as loyalty towards a business partner) that can be materialized through refraining from invoking the defence of limitation. Apart from the preceding, those in favour of a construction taking account of limitation of a claim ad petitionem sometimes point to aspects that would seem secondary and of less importance, that is those constituting the result of such regulation being in force rather than its causes; what I have in mind is the argument that such a construction is harmonious with the potential to invoke the defence outside proceedings as well (Kordasiewicz 2008, 602), or that it is better suited to other provisions of the Polish Civil Code dealing in some capacity with the issue of limitation of claims (Szpunar 2002, 19).

\section{ARGUMENTS EMPLOYED IN SUPPORT OF EX OFFICIO CONSIDERATION OF EXPIRATION OF THE LIMITATION PERIOD ON A CLAIM}

In turn, if we are speaking of those who support a solution in which the expiration of the limitation period on a claim is taken into account ex officio by the court, it should be observed that their arguments are strongly characterized by the desire to protect parties weaker in terms of their economic resources and legal awareness, and thus unable to afford a professional attorney while at the same being in possession of legal knowledge insufficient to determine whether the limitation period of the claim brought against them has expired and that they should themselves raise that defence in court.

At times, particularly in the older legal literature and with the use of the vocabulary fashionable at the time, the mechanism of ex officio taking into account limitation of a claim as a means of preventing the use of limitation of claim as a tool for exploitation (Wolter 1953, 265), and the taking into account of limitation of claims ad petitionem is a solution that favours the interests of the bourgeoisie, by the same token weakening the protection available to individuals unable to afford a professional attorney (Szer 1950, 230). What is more, it is not only said that legal regulation establishing consideration of limitation of a claim solely ad petitionem is a solution that favours economically stronger individuals (those who can afford

${ }^{11}$ This reservation results from the change in the legal regulation made by the Act of April 13, 2018, which will be discussed later in this article. 
representation) and those generally more resourceful, but as a result also leads to different resolutions of cases with the same factual and legal circumstances (depending on whether the respondent was aware of the institution of limitation of claims and set up the appropriate defence and/or employed an attorney who did so); this is difficult for society to accept and breeds both consternation and opposition, as well as leads to belief in the extraordinary powers of lawyers and a loss of trust in the courts (Cagara 1961, 768-769).

The argument is also raised that taking limitation of a claim into account ex officio is more suited to achieving the social function which the institution of limitation is supposed to perform, specifically, the stabilization of legal relations and the elimination of conditions of uncertainty; this objective would not be achieved if limitation were to be dependent on the uncertain and chance circumstances of whether the respondent is aware of having the ability to invoke the defence of limitation, or even if so, whether he will use it, as he be guided by other motivations (Dobrzański 1955, 51-53).

It is also pointed out that taking limitation of a claim into account ex officio removes the odium of unfavourable moral judgements against the debtor's seeking to avoid claims against him by invoking limitation of the claim, for the reason that in every case the court will take into account on its own initiative the fact that the limitation period of the pursued claim has ended, without an application from the respondent, and even without asking for his opinion on the matter (Dobrzański 1955, 55).

\section{ASSESSMENT OF THE JUDGEMENTS PRESENTED ABOVE. POSITION ON THE MATTER OF HOW EXPIRATION OF THE LIMITATION PERIOD IS TAKEN INTO ACCOUNT. THE PRACTICE OF POLISH COURTS REJECTING THE DEFENCE OF LIMITATION ON GROUNDS OF ABUSE OF A RIGHT UNDER ART. 5 OF THE CIVIL CODE}

Of course, we may cite further arguments in support of one of the aforementioned manners of taking into account the expiration of the limitation period on a claim pursued before a court, but considerations of space do not permit us to do so, and the arguments already cited are of fundamental significance for the deliberations being conducted here; the remaining are of a secondary and less important nature (id est they are an effect of the adoption of a particular solution, such as invoking the accomplishment of simplification of the institution of limitation on claims by adopting the ex officio model - see: Wasilkowski 1954, 145. Which itself is also called into question - see Szpunar 1974, 285). That said, what is, for substantive reasons, worthy of note is that the arguments previously mentioned, particularly those concerning the supposed benefits of the model under which a court is to take into account limitation of a claim only in the event the 
party against which that claim is pursuit makes an appropriate motion are less than convincing, and even inconsistent with the actual state of the law in Poland at present. This is frequently the result of certain points of view being expressed in a time when different regulations were in force. A particularly vivid example of such a situation is the obsolescence of the argument that under the model of taking into account limitation ad petitionem, there is no risk of harm to that person in light of the active role of the court which informs a party appearing without an attorney of the possibility to set up such a defence. In the light of the present wording of the Code of Civil Procedure ${ }^{12}$ such an act by the court would be seen as impermissible favouritism towards one of the parties to the dispute, and thus in violation of the general principles governing civil procedure in Poland, such as adversarial process and equality of parties to proceedings (this remark and further considerations, after the entry into force of the already mentioned Act of 13 April 2018, remains valid in relation to all claims other than those claimed by entrepreneurs from consumers). It is true that under Art. $212 \S 2$ of the Code of Civil Procedure, in the event of a justified need the court may provide the parties with vital instructions, but this provision is not understood to allow for substantive support being given to a party by the court (e.g. pointing out there are grounds for invoking the defence of limitation of a claim); rather, it is interpreted as permitting information to be provided as to the possibility of e.g. submitting a motion for relief from court costs and/or for the appointment of an attorney by the court, and instructing a party as to the formal conditions and deadline for submitting an appeal against a judgement (Jędrzejewska 2006, 93). This interpretation of the aforementioned provision finds strong confirmation in the fact that when amending to the Code of Civil Procedure in $2011^{13}$, the legislator added a clear reservation under which the instructions that the court may provide to the parties appearing before it were described using examples such as the possibility of drawing attention to the advisability of employing an attorney. What is more, in the amended Art. 5 of the Code of Civil Procedure ${ }^{14}$ the legislator declares that in the event of justified need, the court may provide necessary instruction to parties and participants to proceedings appearing before the court without the representation of an advocate, legal advisor, patent attorney, or attorney from the State Treasury Solicitors' Office. The scope of instructions which the court is allowed to provide has been clearly limited to issues concerning procedural acts, and does not encompass an indication of the consequences of substantive regulations for the parties (from which it follows that the court may not inform a party that the limitation period set out in the Civil Code or other legislation on the claim being pursued against him has expired, never mind the legal consequences of such, including the possibility of raising such

${ }^{12}$ The Code of Civil Procedure of 17 November 1964 (Dz.U. 2016, item 1822 with amendments).

${ }^{13}$ On the basis of Art. 1(29) of the Act of 16 September 2011 amending the Code of Civil Procedure and some other acts (Dz.U. 233, item 1381).

${ }^{14}$ Under Art. 1(2) of the Act cited in the preceding footnote. 
a defence. This conclusion, although justified differently, is also reached by Adam Jedliński - Jedliński 2012, 735). This solution should be considered appropriate, as it helps to avoid controversy regarding the impartiality required of judges. On the other hand, it is clearly disadvantageous for parties lacking in knowledge about provisions on limitation of claims; they are unable to determine whether a limitation period of a claim has expired (whether the running of the limitation period has been interrupted, suspended, etc.), or they are unaware that the relevant defence must be invoked and they are without professional representation before the court (primarily due to a lack of funds to hire an attorney). In these circumstances the party which is clearly at an economic disadvantage (with neither legal education nor an attorney) is naturally in a worse position in court compared to the party which is stronger in this respect (e.g. a well-off enterprise with the assistance of lawyers). An opportunity to ameliorate this imbalance is adoption of the model under which limitation of a claim is considered ex officio. This model would also facilitate avoiding potentially negative moral assessment of individuals who avoid resolving claims against them by invoking the defence of limitation, as the decision would be taken by the court, and the relevant regulations would require in all circumstances taking account of the fact that a limitation period of a claim had expired.

There also seems to be no justification for the fear that depriving the respondent of the right to decide whether to invoke the defence of expiration of the limitation period will make it impossible for that individual to demonstrate he is in the right on the merits, for example that a doctor is being wrongfully sued for damages because he is not at fault and did not err in the performance of his duties. Firstly, it should be observed that even those raising this argument at the same time declare that it is a quite rare exception. Secondly, it is very difficult to find real examples of judicial disputes during which a party aware of the possibility of invoking the defence of limitation of a claim, thus effecting dismissal of the action, would not do so out of a preference to engage in a substantive dispute and demonstrate the baselessness of the claim being pursued. The absence of such cases has a deeply rational justification. It would be irrational from the economic point of view, a needless waste of time, energy and money on a long process with an uncertain result, whereas the pace of modern life generally inclines people to engage in the most efficient use of those resources. It is obvious that time, attention and finances are better used elsewhere, since one may quickly and easily win a trial by raising the defence of limitation of the claim (insofar as it is justified). Even if the respondent possesses evidence that, in his view, would allow him to prove he is right on the merits and that the action brought against him is baseless, the engagement of financial resources and invaluable time necessary to do so coupled with the risk of failure (e.g. considering that the other party may succeed in proving its claim's merit, or the opinion of a court-appointed expert may demonstrate negligence) does not come across as a solution that 
a rationally-thinking person would choose. ${ }^{15}$ What is more, opting to discard the defence of limitation of a claim and engaging in a potentially long dispute over the merits, even assuming one will ultimately prevail, does not entail any particularly substantial benefits in comparison with a situation where the respondent simple takes advantage of the defence. Indeed, the mere fact of being sued (e.g. in the case of a doctor) for negligence in the performance of his profession and the resulting trial would itself damage the doctor's reputation, causing him to be perceived in light of that fact by society and potential patients in particular. His reputation will therefore be ruined, particularly if the case is highlighted in the media. The resolution in the case will favour him (dismissal of the action) after years of an exhausting trial (which is very likely in Poland), but will not ameliorate the damage suffered by the doctor (loss of patients, profit, promotion, suspension at work and of the right to practice professionally, etc.). What is more, experience demonstrates that, as a rule, public opinion is only presented - if at all - with the conclusion of the proceedings in the sense of who was "victorious" without going into details and explaining why. When taking into account the general conviction that the victor is in the right, it makes no difference whether the suit was dismissed owing to expiration of the limitation period, or because the respondent proved that the claim was baseless on its merits. However, a quick dismissal of the claim owing to the limitation period allows for avoiding the aforementioned negative effects of a long trial (including wasted time, resources, money, and unfavourable social impact), which is a hugely important practical argument.

Doubtlessly as well the model under which the fact of expiration of the limitation period on a claim is taken into account ex officio would help avoid divergence of verdicts in cases with similar legal and factual circumstances, by the same token facilitating development in society of the conviction that all parties are treated equally by courts (which many also believe to be just treatment, although it is not necessary to agree with this, because we must consider what concept of justice we have in mind in this context), or at least that there is no preference extended to those with the financial resources to employ an attorney.

Furthermore, taking into account limitation ex officio would be more consistent with the functions which are generally associated with the institution of the limitation period, including in particular motivating the creditor to relatively quickly conclude the pursuit of his claims, thereby achieving certainty of law (legal safety) that after the end of a specified length of time, nobody will be able to sue a debtor for receivables long past due. The fact that the circumstance of the expiration of the limitation period on the pursued claim is taken into account only ad petitionem, as is presently the case under the regulations of the Polish Civil Code

${ }^{15}$ And even if such an individual were found, this would be an extraordinary situation, certainly with additional motivation to participate in such proceedings; however, these exceptional circumstances should not be the grounds for drafting legal norms, but rather typical and dominant ones, as legal norms are applicable to all of society. 
(except in cases where the entrepreneur has sued the consumer),, allows a creditor in possession of an claim after the expiration of limitation period to pursue it before a court, counting on the respondent not setting up the defence of limitation. What is more, even if this defence is invoked, in many cases it may turn out that the court awards the claim in light of the deeply-rooted jurisprudence of the Supreme Court applied by the common courts, which allows for assessment of the defence of limitation through the lens of Art. 5 Civil Code as an abuse of the law by the party against whom the claim is being pursued; in consequence, the court may reject the defence, and then rule for enforcement of the claim, despite the expiration of limitation period. ${ }^{16}$ Such regulation and jurisprudence rather serves to reinforce uncertainty as to the legal situation applicable to a given claim and its status after the end of limitation period, not only in respect of the creditor (who does not know whether the respondent will raise the defence of limitation) but also the debtor as well (who, in setting up the defence of limitation has no certainty as to whether this will in fact lead the court to dismiss the action). This condition of uncertainty is all the greater when considering there is frequently no way to predict whether a court in a given case will hold that the right is being abused, as courts in the past have rejected the defence of limitation on grounds of abuse as defined under Art. 5 Civil Code not only when it could be easily judged as such (e.g. the debtor was in talks with the creditor and gave assurances that he would soon repay the debt, after which then it occurred that this was only a manoeuvre to run out the clock on the limitation period and prevent the creditor from bringing an action in time), but also in situations rather surprising in that context; even when the debtor was not at fault and cannot be said to have acted in bad faith, or even had no knowledge of the relevant circumstances. ${ }^{17}$ In addition, the debtor can surprise his remaining creditors by renouncing the defence of limitation in the event of being sued by one of them; this possibility is afforded to him by the regulations presently in force

${ }^{16}$ Inter alia judgment of the Supreme Court of 13 September 2012, V CSK 409/11, Lex no. 1230163; judgment of the Supreme Court of 1 December 2010, I CSK 147/10, Lex no. 818558; judgment of the Supreme Court of 9 July 2008, V CSK 43/08, Lex no. 515716; judgment of the Supreme Court of 16 February 2006, IV CK 380/05, Lex no. 1799977; judgment of the Supreme Court of 6 October 2004, II CK 29/04, Lex no. 194131; judgment of the Supreme Court of 7 June 2000, III CKN 522/99, Lex no. 51563; judgment of the Supreme Court of 9 February 2000, III CKN 594/98, Lex no. 520031; judgment of the Court of Appeals in Łódź of 6 June 2014, I ACa 1533/13, Lex 1480475; judgment of the Court of Appeals in Katowice of 24 May 2013, I ACa 157/13, Lex no. 1327520; judgment of the Court of Appeals in Szczecin of 24 April 2013, I ACa 36/13, Lex no. 1375878; judgment of the Court of Appeals in Kraków of 21 November 2012, III APa 29/12, Lex no. 1236897; judgment of the Court of Appeals in Warsaw of 12 April 2011, VI ACa 1374, Lex no. 1143498 and many other rulings.

${ }^{17}$ See e.g. judgment of the Supreme Court of 25 February 2010, V CSK 242/09, OSNC 2010, no. 11, item 147; judgment of the Supreme Court of 16 November 2005, V CK 349/05, Prawo i Medycyna 2007, no. 1, p. 133; resolution of the Supreme Court of 29 November 1996, II PZP 3/96, I PK 48/11, Lex no. 1125243; judgment of the Court of Appeals in Warsaw of 12 October 2012, I ACa 376/12, Lex no. 1238221. 
(Art. $117 \S 2$ Civil Code). With this normative solution, which entails taking into consideration limitation ad petitionem (and allows for renouncement of it) and the jurisprudence which has developed on its basis, there is no chance of achieving legal certainty regarding a specified claim thanks to the institution of limitation. Similarly, it cannot be viewed as a solution that provides motivation for creditors to pursue claims before the expiration of their limitation period, since even after that time it is possible to effectively do so before a court (e.g. if the debtor renounces the right to invoke the defence, or simply fails to invoke it before the court, or after invoking it the court rejects it on grounds of abuse).

The remaining arguments cited in favour of allowing the defence of limitation ad petitionem can also be disputed in a similar manner; for example, a more in-depth analysis of the provisions of the Civil Code demonstrates they are not particularly well-harmonized with such a solution - either they are irrelevant, or even in opposition (for a broader analysis of the issue: Kuźmicka-Sulikowska 2015, 476-477).

\section{POLITICAL MOTIVATIONS FOR A CHANGE IN THE LAW CONCERNING THE MANNER OF TAKING INTO ACCOUNT EXPIRATION OF THE LIMITATION PERIOD IN THE POLISH CIVIL CODE. A HIDDEN LEGAL RELIC}

Here, however, with consideration to the subject matter of these divagations, it is necessary to pay particular attention to the fact that the moment in time the change made in the Polish Civil Code consisting in a shift from a model under which limitation was taken into account ex officio to one in which it is taken into account only ad petitionem at the initiative of the party against which the claim is pursuant is significant. As has been mentioned already, this occurred in 1990, and we cannot fail to see the link between what must be termed a radical change in the law with the breakthrough changes in the Polish political order which took place in 1989 and, in a broader sense, the transition from communism to democracy; in the geopolitical sense this involved exiting the Soviet sphere of influence (to put it mildly) and an attempt at developing closer relations with the countries of Western Europe. Against this backdrop, the tendency to automatically reject everything associated with the Soviet past, all solutions, including legal ones, comprising a sort of 'legal transplant', ${ }^{18}$ comes as no surprise. In conjunction with

${ }^{18}$ For more on "legal transplants": Watson 1991, 73; Watson 1993, 21; Mattei 1994; Szpak 2011, 57. See also Miller 2003, 845-868. It should be noted that the typology of legal transplants developed by the last author does not necessarily allow for it to classify the transplant I write of in this article. This is likely the result of the fact that the author does not have direct experience with the reality of Poland during the Stalinist era and the imperial policy conducted by the USSR. Doubtlessly, thus, in this case we are not dealing with what that author distinguishes as 'the costsaving transplant', 'the entrepreneurial transplant' or 'the legitimacy-generating transplant'; 
these changes it was thus determined necessary to eliminate from the Polish Civil Code regulations determining the ex officio consideration of limitation of claims as a model taken from Soviet law (the fact of its provenance is not contested), and in their place to introduce models accepted in the legal systems of European states. This is the description given in the literature on the Polish civil law of the model under which the circumstance that the limitation period of a pursued claim has expired is only considered by the court when the party against which the claim is pursued invokes the defence of limitation. It is strenuously emphasized that the introduction of such a model into the Polish Civil Code following the changes of 1989 is an obvious necessity, as it is the same one in use in other European countries. Clearly, then, one factor in the Polish Civil Law's transition from taking limitation of claims into account ex officio to ad petitionem is the drive to immediately and radically repudiate all aspects of Soviet law, as well as to introduce legal solutions that function within the countries of Western Europe. Against this backdrop it is worth observing that it would seem such a direction of changes in the law, strongly motivated by obvious political considerations, was done somewhat unthinkingly. Indeed, scholars generally quite thorough in their publications who, at the time, argued in favour of taking limitation of claims into account $a d$ petitionem clearly felt that the ultimate argument for why such a model should be adopted was that it is the one present in European legal systems; ${ }^{19}$ these authors thus did not even perceive the need to cite any examples of legal norms from particular countries where this solution was employed, nor - what is more surprising - they even did not bother to research data on the function of such a solution in practice, to learn whether it is positively assessed in places where it us used. It should be noted that this approach is widespread (Szpunar 2002, 19; Brzozowski 1992, 26; Brzozowski 2008, 525; Wójcik 1991, 48; Pałdyna 2012, 254; Kordasiewicz 2008, 602).

Meanwhile, it would seem that such a one-dimensional view on the matter and rejection of a given solution only because it has some association with the previous political order, as well as treating as an imperative the implementation in its place of a model in effect in states which feature the political order that

what is more, despite what the name might suggest, this is not the last type distinguished by the author, namely 'the externally dictated transplant', as this is understood to mean acceptance by an economically weaker family state of certain legal solutions imposed by a stronger state or international organization as a condition of e.g. trade between the two, or of refraining from excluding the weaker from trade. However, in the transplant under consideration in this article, we are also dealing with pressure to adopt a certain solution, but of an entirely different etiology.

${ }^{19}$ Here we may perceive something like "the legitimacy-generating transplant" according to Jonathan Miller, where the legal authority necessary for a newly-introduced solution is provided essentially by the prestige of the foreign model itself (Miller 2003, 845 et seq.). See also emphasis of the role of this factor in judicial decisions: Watson 1996, 351. The occurrence of this type of legal transplant is perceived precisely as of significance for countries emerging from a long period of despotic governments (Szpak 2011, 66). 
we desire to emulate, is difficult to justify. There is no substantive approach to the issue, no assessment of the practical effects of the functioning of the two competing solutions, no consideration of the goals we wish to achieve using a given legal institution where only after serious consideration do we decide which solution will better serve those goals, without associating the decision with needless emotional factors. In light of the political backdrop that has been elaborated of the 1990 introduction of changes in the model under which the expiration of the limitation period was taken into account in the Polish Civil Code, we may not escape the impression that this took place without any reflexion, or even with the a priori assumption that such reflection will not be entered into, as the solution adopted in the times of socialism is bad for the very reason that it was adopted then, and should for that same reason be changed. We may clearly perceive a particular process of discrediting solutions adopted in Poland during the socialist period. In the phase of conflict between Solidarity and the communist party, the discourse of the opposition party was based inter alia on undermining the government's legitimacy, accusations of betraying Poland and abandoning it to Soviet influence. Patriotism and memory of Poland's history were invoked, in particular about independence movements which took the form of uprisings. Against this backdrop, the socialist state was assigned solely negative attributes, and was presented as an external entity in respect of individuals (Charkiewicz 2007, 61). However, the resulting automatic treatment of all legal solutions with a Soviet pedigree as "bad" and their elimination after the political changes of 1989 from the Polish legal order should not necessarily be seen as something which turned out well for Poles; I have shown this on the example of the change made at that time in the manner of taking into account the expiration of the limitation period on a claim. From a model generally assuming this was done ex officio, and thus with equal treatment of all, including less financially well-off and legally aware respondents, preventing the pursuit against them of claims when limitation period expired, in 1990 the law transformed into a model under which the expiration of the limitation period is taken into consideration ad petitionem; this solution clearly favours more aware respondents and those the financial wherewithal to hire an attorney with the capacity to set up this defence. Therefore, with this particular observation in mind, we can agree with E. Dunn who calls into question whether the post-socialist transformation in Poland can be considered as an absolute success, considering the changes made by it serve to increase disparities and deprive of power the same workers who had previously taken the fight to the socialist state. The referenced author demonstrates that neoliberalism, in its drive to liquidate institutions of the socialist state, primarily destroyed what the most valuable aspects of the socialist era from the social point of view - this is no apology for socialism, but merely an indication that there were some elements of reality from that era which people would be glad to retain, including various forms of levelling the economic situation of members of society (Dunn 2008, 
193). In light of the analyses conducted in this article there is no way to escape the impression that the loss of a legal solution desirable from the social point of view occurred precisely within the framework of the changes made in 1990 to the Polish Civil Code regarding the manner in which consideration is given to the expiration of the limitation period.

The position presented here also draws support from the view convincingly articulated recently in the relevant subject literature that rejection of certain solutions is not always justified solely on the grounds that they comprise legal relicts (Mańko 2015, 207-208), and should not be treated as pathologies but rather as a natural characteristic of the legal culture (Mańko 2016, 67, 86-89). Such a relict should be sought in the context of Polish jurisprudence applied presently to the question of limitation of claims.

It is true that the concept of 'legal relict' is generally understood to mean a particular type of legal phenomenon (norm, concept, institution) which was implemented during an earlier social and economic phase under the influence of factors specific to it, and which, following transformation of the political order, was not eliminated from the legal order (Mańko 2015, 187, 191-192); thus, on first glance it may come across as strange that I mention this here as just a moment ago I clearly indicated that within the framework of the political transformation that took place in Poland in 1989 and the associated revisions to the Polish Civil Code, provisions requiring the court to take expiration of the limitation period of a claim ex officio were stricken and replaced with regulations involving giving such consideration ad petitionem. However, it should be considered that here I perceive not a classic 'normative' relict (a provision or construction retaining its unaltered shape in spite of a change in the prevailing political order; Mańko 2015, 192), but rather a type of relict called a "hidden relict". This concept is understood to encompass situations in which the language of a legal text formally does not indicate continuity (to simplify: the further existence of a legal solution from the previous regime), yet this continuity can be identified at the level of judicial practice (Mańko 2015, 196, 199-200). It would seem to me that we are dealing with just this type of legal relict in the case under consideration here. In spite of the formal derogation of the norm requiring consideration of limitation of claims ex officio and the present norm assuming consideration ad petitionem, courts are clearly striving to maintain the previous legal order in respect of the issue at hand - because then it was up to the courts to decide about the effects of expiration of the limitation period (not asking the parties for their opinion courts dismissed an action, although they could have chosen exceptionally to not take into account the circumstance of expiration of the limitation period under Art. 117 § 3 Civil Code, what made them "masters of the situation” within the scope encompassed by the application of that provision, and thus in respect of claims whose limitation period did not exceed three years; they could either take limitation of claim into consideration and dismiss the action, or not and award such a claim essentially as 
they saw fit - the factors limiting the court's discretion were not made restrictive by the legislator, and were in fact quite freely and broadly defined [id est it was up to the court to decide that the delay in pursuing the claim was not excessive and was justified by some exceptional circumstances], which gave the court discretion to decide in a given case whether to take account of the expiration of the limitation period or not). Presently, however, courts - evidently striving to maintain this status quo - in their case-law have usurped for themselves the right in cases where limitation of claim is invoked ad petitionem to reject this defence by holding it to be an abuse of a subjective right under Art. 5 Civil Code. Courts have thus decided and consolidated the position in their caselaw (and to be precise, the position was first taken by the Supreme Court, then adopted by common courts ${ }^{20}$ ), that they may assess the invocation of the defence of limitation of claim through the lens of whether the respondent is making use of his rights in a manner contrary to its social and economic purpose and/or the principles of social coexistence (those criteria are set out in Art. 5 Civil Code). This judicial practice gives rise to serious doubts. First, because we may question whether the category of defences (to which limitation of claims belongs) can be classified as a subjective right, and what follows, of whether the aforementioned Art. 5 Civil Code applies to them, which expressis verbis addresses cases of abuse of a right he possesses. ${ }^{21}$ Secondly, this practice can be assessed as the form of proceeding contra legem - since the legislator removed from the text of the law the norm establishing consideration of expiration of the limitation period ex officio and introduced a model under which it is done ad petitionem, the behaviour of courts which nevertheless hold that they may act ex officio and ignore the raising of this kind of defence, awarding the claim despite its limitation period expired and invoking - in a quite elusive and vague manner - the principles of social coexistence, is clearly in contradiction with the law as it is written. However, what is of particular importance from the perspective of these deliberations is that, at the practical level, this line of jurisprudence has petrified the aforementioned practice of courts deciding on their own, ex

${ }^{20}$ See inter alia the judgements referred to in previous footnotes: Inter alia judgment of the Supreme Court of 13 September 2012, V CSK 409/11, Lex no. 1230163; judgment of the Supreme Court of 1 December 2010, I CSK 147/10, Lex no. 818558; judgment of the Supreme Court of 9 July 2008, V CSK 43/08, Lex no. 515716; judgment of the Supreme Court of 16 February 2006, IV CK 380/05, Lex no. 1799977; judgment of the Supreme Court of 6 October 2004, II CK 29.04, Lex no. 194131; judgment of the Supreme Court of 7 June 2000, III CKN 522/99, Lex no. 51563; judgment of the Supreme Court of 9 February 2000, III CKN 594/98, Lex no. 520031; judgment of the Court of Appeals in Łódź of 6 June 2014, I ACa 1533/13, Lex 1480475; judgment of the Court of Appeals in Katowice of 24 May 2013, I ACa 157/13, Lex no. 1327520; judgment of the Court of Appeals in Szczecin of 24 April 2013, I ACa 36/13, Lex no. 1375878; judgment of the Court of Appeals in Kraków of 21 November 2012, III APa 29/12, Lex no. 1236897; judgment of the Court of Appeals in Warsaw of 12 April 2011, VI ACa 1374, Lex no. 1143498 and many other rulings.

${ }^{21}$ Correct remarks on the subject also from: Wilejczyk 2014, 249-250. 
officio, as to the effects of the expiration of the limitation period. What is more, it would seem that under the present Polish law, we may observe normative signs of a return to this model within the framework of regulations on electronic smallclaims proceedings, of which more will be said in a moment.

Here is it worth observing that a similar conclusion, albeit applying somewhat different logic, has been reached by R. Mańko, who here sees a hidden legal relic in the form of the court's discretional authority to take into consideration the expiration of the limitation period on a claim. However, this author sees the relic in a slightly different light. Specifically, applying - as he calls it - "a broad analytical approach", he does perceive the relic in the sphere of case-law, not legislation, but points out that it is grounded in the wording of Art. $117 \S 3$ Civil Code in effect prior to 1 October 1990; this provision gave the court the possibility to influence the effects of expiration of the limitation period. The striking of this provision did not, however, deprive courts of this influence as the Supreme Court has allowed that courts may seek grounds for annulling the effects of the limitation period's expiration in other provisions of the Civil Code, particularly those containing general clauses (Mańko 2015, 206); naturally, in this context Art. 5 Civil Code comes to the fore.

This is not, however, an entirely convincing position. Within the framework of legal solutions in force under the previous political order, courts generally had to take limitation into account ex officio (except in cases where the entrepreneur sues the consumer), and only by way of exception could they invoke Art. 117 $\S 3$ Civil Code to avoid doing to in the event of extraordinary circumstances concerning claims whose limitation period did not exceed three years. Presently, however, under the law as it is written, courts are not permitted to take limitation into account ex officio, but only ad petitionem (submitted by the party against which the claim is pursued); it is courts which have usurped for themselves the potential to interfere ex officio through holding the use of such a defence to be an abuse of one's rights, and therefore awarding the claim in spite of expiration of its limitation period - which they do on grounds of Art. 5 Civil Code, while expressing the reservation that the application of this provision as a lens for assessing the defence of limitation can only occur in exceptional circumstances. To summarize: it must be pointed out that the previous rule was different - taking limitation into account ex officio, with exceptions as to when the court did not do so, whereas the rule today is considering limitation ad petitionem (except in cases where the entrepreneur sues the consumer), with exceptions when the court, in spite of invocation of the defense of limitation of claim, decides ex officio to award the claim. In this respect I see no continuity of the legal solution in the context of the manner in which expiration of the limitation period is taken into account by Polish courts. That said, I do perceive it in something else - in the retention of the model under which the court decides ex officio as to the effects of the expiration of the limitation period. Prior to 1 October 1990, this was done 
on the basis of a specific provision of the law, whereas after that time it was grounded in case-law invoking Art. 5 of the Civil Code in support; ${ }^{22}$ this tendency is receiving reinforcement at the statutory level, an excellent example of which is supplied by regulations concerning electronic small-claims proceedings.

\section{ELECTRONIC SMALL-CLAIMS PROCEEDINGS AND THE ISSUE OF LIMITATION OF CLAIMS}

To provide at least a general outline of the issue for readers who are not familiar with all the minutiae of the Polish legislative process and its socioeconomic backdrop, it should be pointed out that within the framework of the Polish civil procedure, following a great number of proposals in this area, the possibility of using computerized means of communication has been admitted within a limited scope; this includes regulation in the Code of Civil Procedure governing electronic small-claims proceedings. However, shortly thereafter some undesirable elements cropped up - entities whose commercial activity consisted in the purchase of receivables and then seeking enforcement began to ruthlessly take advantage of their significant advantages (teams of lawyers, capital) over debtors by filing e-actions where e.g. an erroneous address of the debtor was purposefully provided. As a result, the court's warrant for payment was thus not properly served, and as a result the deadline for entering an objection expired (Potejko 2010, 16 et seq.), which meant that the debtor did not learn of the case against him until enforcement proceedings were underway. ${ }^{23} \mathrm{I}$ mention this in the context of the present divagations because it should be noted that this manner of pursuing claims was employed on a large scale to pursue claims which limitation period expired. Thus we should not be surprised by the negative assessment of such exploitation of the law as detrimental to the interests of the weakest debtors who are unfamiliar with the law and deprived in the foregoing manner of the possibility to plead their case before a court. Understanding this situation, on 10 May 2013 the parliament passed legislation amending the civil procedure, ${ }^{24}$ which intended to eliminate

${ }^{22}$ This is why at a more general level I can concur with the opinion of Rafał Mańko, if continuity is to be found in how the discretionary authority of the court as concerns taking into consideration the expiration of the limitation period on a claim (Mańko 2015, 206).

${ }^{23}$ It is another thing that this has been the fate of debtors for other reasons as well (e.g. because of the widespread conviction that if you do not accept a registered letter containing a warrant of payment, the warrant has no legal effect, whereas the presumption of notice being served is applied under which two unsuccessful attempts at delivery are treated as though the notice had, in fact, been served to its addressee; many people ignore as well the fact that the deadline for entering an objection to a warrant of payment is quite short, under the conviction that there will be a later possibility to employ some legal means of proving one's claim, what isn't true).

${ }^{24}$ This refers to the Act of 10 May 2013 amending the Code of Civil Procedure (Dz.U. 2013 item 654), in force from 7 July 2013. 
such abuses. The changes included introduction of the obligation to provide precise information identifying the respondent, including PESEL (number in the Universal Electronic System for Registration of the Population) and NIP (taxpayer ID number) if the individual is obliged to possess one or possesses one without being under a duty to do so (Art. $505^{32} \S 2$ point 1 Code of Civil Procedure). The complainant is also required to provide the pursued claim's due date (until July 8, 2018 it resulted from art. $505^{32} \S 2$ point 3 Code of Civil Procedure, and from July 9, 2018, as a result of the amendment made by the Act of April 13, 2018, such an obligation follows from Art. $187 \S 1$ point $1^{1}$ of the Polish Code of Civil Procedure). This last solution, combined with other new regulation under which electronic small-claims proceedings can only be used to pursue claims which came due in a period of three years prior to the day of the action being filed (Art. $505^{29 a}$ of the Code of Civil Procedure), is generally understood as a step by the legislature to prevent the pursuit of claims after expiration of limitation period via electronic small-claims proceedings (see e.g. Flaga-Gieruszyńska 2014, 986; Infor 2017; Vis Legis 2017). We are evidently dealing with a paternalistic approach by the legislature, which desires to protect "weaker" (debtors without the relevant legal knowledge and assistance of an attorney) players from the "stronger" ones (professional debt-collection companies), and this to a greater extent than in respect of considering limitation of a claim ex officio - it consists of taking it into account at the statutory level, before judicial proceedings are initiated. This results from the possibility to pursue only those claims which came due not later than in the three years before the submission of the action (which is an evident move towards ensuring that on the day of the action's submission a limitation period of a given claim is not expired, as many claims have a three-year limitation period [including those under Art. 118 of the Civil Code for payment provided regularly and payment associated with commercial activity, unless otherwise determined by statute], and the limitation period, pursuant to Art. $120 \S 1$ of the Civil Code, runs from the day on which the claim came due).

However, as to the question of whether the legislature has really succeeded in creating a mechanism to protect weaker parties, we may have significant doubts. Primarily it should be observed that while the aforementioned amendments to the Code of Civil Procedure in 2013 introduced Art. $505^{32} \S 3$ did give courts the power to impose a fine on a complainant, statutory representative or attorney who, either in bad faith or out of failure to take appropriate measures, gave incorrect information listed in Art. $505^{32} \S 2$ point 1 and/or point 2 and Art. $126 \S 2$ point 1 of the Code of Civil Procedure, this fine cannot be imposed for giving incorrect information as to the maturity of the pursued claim, even if done purposefully and in bad faith (Art. $505^{32} \S 3$ of the Code of Civil Procedure does not list Art. $505^{32}$ $\S 2$ point 3, nor does it sanction violations of Art. $505^{29 a}$ of the Code of Civil Procedure). There is thus no threat of a fine in respect of attempts to pursue via electronic small-claims proceedings those claims which came due earlier than 
within three years of the day of the action's filing. What is more, the court is in fact deprived of the possibility to verify the date of the claim's maturity as given by the complainant, as evidence is not included with the action (under Art. $505^{32} \S 1$ of the Code of Civil Procedure, the complainant should indicate in the action what evidence exists in support of his claims, but this evidence is not attached to the claim itself). The court this has no way of examining information provided by the complainant, as there is no evidence to compare it to (owing to lack of access); all the court can do is to trust in the declarations of the complainant and assume their truthfulness (Tchórzewski, Telenga 2010, 43-44; Franczak 2017, 50; Potejko 2010, $17)$, which can at times be a counter-factual assumption.

The opportunity to make such an examination arises only in the event of an objection against the warrant of payment (and whether this is possible in practice depends on the effects of the aforementioned new regulations concerning identification of the complainant, and thus whether the warrant of payment was properly served - to the correct respondent, and not e.g. another person of the same name) and assignment of the matter to a court with jurisdiction under general provisions (Art. $505^{36} \S 1$ of the Code of Civil Procedure), which will hear the case (of course, if all the necessary requirements are fulfilled, including those in Art. $505^{37}$ of the Code of Civil Procedure). However, in the meantime the court will be able to dismiss an action for a given claim on grounds of limitation of claim only when the respondent raises the defence of limitation - and in this case we return to the general provisions governing limitation of claims. At the same time, all the previously discussed reservations concerning consideration ex officio of limitation of claims apply. This also clearly conflicts with the objectives the legislature claims to be guided by when introducing the aforementioned amendments in 2013; here we have no mechanism for protection of weaker parties (in the context of legal awareness and financial resources).

Furthermore, it should be noted that the model of electronic small-claims proceedings developed with the aforementioned goal in mind does not necessarily itself constitute an effective mechanism for reasons other than those already discussed. For example, we may indicate that the limitation consisting in the possibility of pursuing in those proceedings only claims which came due in the three years preceding the day of submission of the action does not exclude the pursuit of an claim after the expiration of limitation period, meeting that criterion. This is because many claims have a shorter limitation period than three years (such as claims from widespread contracts of sale, which under Art. 554 of the Polish Civil Code are subject to a two-year limitation period). Such a claim can come due two years and eight months prior to submission of the action, limitation period expired after two years, and yet on the day of the action is brought it fulfils the aforementioned condition, as it came due in the three years prior to the initiation of the court action. On the other hand, we may also observe that the length of the standard limitation period for claims in the civil law according to the Polish Civil 
Code is 6 years (Art. 118 in wording binding from $9^{\text {th }}$ of July 2018; earlier it was 10 years), and thus there will be many claims which, in spite of coming due more than three years before the day of submission of an action in pursuit of them, would not be after expiring them limitation periods at the moment of filing suit in order to pursue them after the passing of more than three years from the date of their maturity.

\section{CHANGES IN THE LEGAL REGULATION MADE BY THE ACT OF APRIL 13, 2018}

The above-mentioned social phenomena, in particular the perception of a mechanism in which limitation is only taken into account when a defendant raises a complaint, as a harmful poor person, without financial means to receive the help of a lawyer, caused the Polish legislature to react to it. This reaction took the form of the Act of 13 April 2018 amending the Act - Civil Code and some other acts ${ }^{25}$ that entered into force on July 9, 2018. It brought with it another fundamental turn with regard to the manner in which the expiry of the limitation period in Polish civil law is taken into account. Namely, with regard to claims that entrepreneurs have against consumers, the legislator ordered from now on that the court's should take into account ex officio, that the limitation period has expired (Article $117 \S 2^{1}$ interpreted in conjunction with Article $22^{1}$ of the Polish Civil Code). This change in the justification of this law was motivated by the fact that in this way the aim is to obtain legal certainty as to the claim by virtue of expiration of the limitation period. Despite this declaration, the real shape of the introduced regulations does not fully support its implementation, because at the same time the court was given the opportunity to consider of the parties' interests and fairness, and fail to take into account the expiration of the limitation period of the claim against the consumer, and, however, to award the claim against him (Article $117^{1}$ of the Polish Civil Code). It should also be stressed that in relation to all other claims (that is, other than those claimed by entrepreneurs from consumers), the existing solution has been maintained, that is to take into account the expiration of the limitation period only to the plea raised by the debtor. This results in a rather strange duality in the ways of taking into account the expiration of the limitation period in Polish civil law, where the question which method will come into play in a given case depends on whether the person against whom the claim is entitled will be qualified as a consumer, or not.

The above also leads to the conclusion that in fact the Polish legislator considered the weaker entities, requiring special legal protection in the context of prescription, consumers and this social group is protected by the

\footnotetext{
${ }^{25}$ Dz.U. of 2018, item 1104.
} 
provisions of the above mentioned Act of 13 April 2018, moreover not only those indicated above, but also, for example, on the basis of its intertemporal regulations. To illustrate this, it can be pointed out, for example, that although the abovementioned act shortened the basic period of limitation of claims from 10 to 6 years and generally to claims arising before the date of entry into force of this law (ie before July 9, 2018) and which limitation period didn't expire before that date, there should be applied from that day the provisions of the Polish Civil Code in the wording after this amendment (Article 5 paragraph 1 of the Act of April 13, 2018), but the situation of entrepreneurs and consumers has been shaped diametrically differently. Namely, for the former (similarly to all relations other than those in which the consumer would be a creditor), the said amendment will generally shorten the time for pursuing claims, because either this new, shortened period of limitation will start running from the day that the amendment enters into force, or if, however, the period of limitation began before the date of entry into force of this Act and it would end earlier if taking into account the previous limitation period, the period of limitation ends that earlier date (Article 5 paragraph 2 of the Act of April 13, 2018). However, in the situation in which the claim is due to the consumer, and was created before the date of entry into force of the Act of April 13, 2018 and on that day the limitation period hasn't been finished, and was subject to the limitation period specified in Article 118 or art. $125 \S 1$ of the Polish Civil Code, the provisions of the Polish Civil Code in the previous wording are applicable, and so the limitation period of these claims shall expire within 10 years (pursuant to Article 5 paragraph 3 of the Act of 13 April 2018). What's more, the legislator went so far as to favor the situation of consumers, that it accepted, that outdated claims against the consumer, which until the day of entry into force The Act of April 13, 2018 no plea of limitation has been lodged, are subject from 9 July, 2018 to the limitation effects set out in the Civil Code, as amended by the Act of 13 April 2018, and therefore the court will have to take into account the expiration of the limitation period ex officio. This may raise doubts as to the fairness of such a solution in relation to entrepreneurs who filed a lawsuit against consumers at a time when this regulation was not in force and they could count on the action being awarded (because, for example, the debtor would not plead the statute of limitations), and now they will lose as a result of a change in the legal regulation, as a result of which the court will take into account the expiration of the period of limitation ex officio. All the more so because this is also facilitated by the law of April 13, 2018 (pursuant to Article 2 thereof, it was added item $1^{1}$ in Article $187 \S 1$ of the Code of Civil Procedure) the requirement to submit, from July 9, 2018, in lawsuits for awarding a claim indication of the due date of the claim. Interestingly, in view of the general wording of this new provision, this requirement applies to all matters, irrespective of whether the expiration of the limitation period of the claim is taken into account by them ex officio or 
on an complaint; which, in relation to the latter, raises serious doubts, because it immediately draws the attention of the defendant to the issue of limitation of the claim, seriously disrupting the balance of the parties' procedural position.

\section{FINAL CONCLUSIONS}

In summary, it should be observed that the change introduced into the Polish Civil Code in 1990 consisting in a transition from the model under which limitation of a claim is taken into consideration at the initiative of the court to one under which the court takes into consideration an expiring limitation period of a claim only in the event when the defence of such limitation is set up against it by the party against which the claim is pursued was clearly motivated by the political transformation that came about in 1989 in Poland, as well as the emotions associated with it. These emotions demanded the most expeditiously possible rejection of everything that could be considered "Soviet", and to absorb the legal solutions present in Western European countries. Thus, on the one hand, this was an attempt at literally freeing ourselves in all aspects from the Soviet sphere of influence (including in legal regulations), while on the other hand a sort of "aspiration" to become westernized, with the a priori, silent assumption that everything from there is better than what we have here. As the experience of the twenty-plus years since then has proven, this has not always been true, including in the legal sphere. The practical functioning of many institutions has demonstrated that not all Western solutions are necessarily beneficial for us - if for no other reason than they are incompatible with other elements of our reality, mentality, etc. At times it is the case that a given solution, although in effect in Western European countries, is also criticized there for its undesirable social impact, etc. However, in adopting a great deal of solutions from there, nobody here took those things into consideration, nobody examined the practical functioning of those legal institutions. This was also the case in respect of adoption into the Polish civil law of the model under which consideration of limitation of a claim is taken into account only ad petitionem rather than ex officio. As has already been demonstrated, this solution is preferred in the Polish legal scholarly literature only because it is "Western" and "not Soviet", even without providing specifics as to where it is in effect, never mind exploring the practical effects of such regulations.

Meanwhile, various phenomena are beginning to demonstrate a clear longing for the model in which limitation of claims is accounted for ex officio. One of the primary ones indicated already is the judicial practice of Polish courts, initiated by the Supreme Court, within which the courts did not allow the party against which the claim is pursued to have the last word as to what potential effects the pursuit of an claim after the expiration of its limitation period would have (and thus in effect the courts rejected the decision of the legislature in 1990 which imposed 
consideration of limitation of claims ad petitionem). They created for themselves a means by which, in the event of invocation of the defence of limitation, they could submit that claim to review; as grounds for this activity they invoke Art. 5 of the Civil Code (the question of whether they are entitled to do so remains highly controversial).

What is more, as has been shown in this article using the example of the peripeteia associated with the provisions of the Polish Code of Civil Procedure concerning electronic small-claims proceedings, the legislature itself is beginning to perceive the need for protection of weaker parties against the effects of the current provisions on limitation of claims as it can only be taken into consideration ad petitionem. By "weaker" I understand poorer respondents who cannot afford professional representation, and do not themselves possess the relevant legal knowledge. It is not sufficient to counter this by arguing that they can apply for a court-appointed attorney - in polish courts' practice this is not an easy thing to do, it must be demonstrated that one is not in a position to bear the costs of remuneration for an advocate or legal advisor without harming one's ability to maintain oneself and one's family, filing - under pain of criminal liability - a detailed declaration on the condition of one's family, income and sources of maintenance. In practice, the courts frequently do not admit such applications, even from people who are objectively poor, with the explanation that awareness of the approaching court case means they should have begun earlier to set aside funds for that purpose.

The step taken by the legislature to exclude in statute the potential to pursue claims after the expiration of limitation period, consisting in provisions on electronic small-claims proceedings that they may only be used to pursue claims which came due in a period of three years prior to submission of the action, is a clear signal that at the legislative level we may see a "longing" for the solution assuming ex officio consideration of limitation of a claim. This model, for the reasons cited above, does, however, have its faults which prevent it from being judged a successful attempt by the legislature at protecting weaker parties from having claims after expiration of limitation period pursued against them.

Against this backdrop it would seem that instead of "smuggling in" a solution under which limitation of claims is taken into consideration ex officio, whether by way of judicial practice or through particular legal solutions, it would be advisable to consider a general return to the principle of limitation of claims being taken into account ex officio by the court as the rule. This solution is, as demonstrated already, the object of desire, although not necessarily in a conscious manner; besides, it would go much further in performing the primary functions assumed for limitation of claims, including the achievement of legal certainty in the context of a given claim, as well as providing creditors with strong motivation to pursue claims in a timely manner. The fact that the earlier norm of taking limitation into account ex officio was borrowed from Soviet law is here a secondary 
consideration, while the rejection of that solution for political and emotional reasons is overshadowed by the substantive arguments in favour of it. And as has been sufficiently demonstrated above, legal relicts are not ex definitione bad, and they may not be rejected for the sole reason that they are relicts.

The changes introduced by the Act of April 13, 2018, discussed in this article, are in fact a partial return to this relict, restoring, at least partially, taking into account the expiry of the limitation period ex officio, which is an evident response to the above-mentioned public needs in this area. However, because this resulted in a kind of dualism in the ways of taking into account the expiration of the limitation period of claims in Polish civil law - ex officio when the entrepreneur sues the consumer, and in all other situations only if the defendant raises an appropriate charge - disputes can be expected as regards the qualification of claims as being claimed from the consumer, and perhaps anticipate an increase in emphasis on introducing the consideration of the expiration of the limitation period ex officio in all cases.

\section{BIBLIOGRAPHY}

Broniewicz, Witold. 1965. "Przedawnienie roszczeń w stosunkach między jednostkami gospodarki uspołecznionej według kodeksu cywilnego". Przeglad Ustawodawstwa Gospodarczego 3: $61-65$.

Brzozowski, Adam. 1992. "Nowa regulacja przedawnienia w prawie cywilnym". Państwo i Prawo 3: $21-31$.

Brzozowski, Adam. 2008. „Tytuł VI. Przedawnienie roszczeń”. In Kodeks cywilny. Komentarz do artykułów 1-44911. Vol. I. 522-537. Edited by Krzysztof Pietrzykowski. Warszawa: C.H. Beck.

Cagara, Jan. 1961. "Na temat przedawnienia i prekluzji słów kilka”. Nowe Prawo 6: 767-770.

Charkiewicz, Ewa. 2007. "Od komunizmu do neoliberalizmu. Technologie transformacji". In Zniewolony umyst 2. Neoliberalizm i jego krytyki. 23-84. Edited by Ewa Majewska, Janek Sowa. Kraków: Korporacja Ha!art.

Dobrzański, Bronisław. 1955. "Problemy kodyfikacyjne przedawnienia. Uwagi na marginesie artykułu J. Gwiazdomorskiego pt. 'Podstawowe problemy przedawnienia'”. Nowe Prawo 2: $50-58$.

Dobrzański, Bronisław. 1960. “Czy uzasadnione jest zachowanie w kodeksie cywilnym PRL różnicy między przedawnieniem a terminem zawitym?” Nowe Prawo 6: 813-819.

Domański, Ludwik. 1936. Instytucje kodeksu zobowiąań. Komentarz teoretyczno-praktyczny. Część ogólna. Warszawa: Marian Ginter - Księgarnia Wydawnictw Prawniczych.

Dunn, Elisabeth. 2008. Prywatyzując Polskę. Warszawa: Wydawnictwo Krytyki Politycznej.

Flaga-Gieruszyńska, Kinga. 2014. "Objaśnienia do art. 4841-50577". In Kodeks postępowania cywilnego. Komentarz. 909-992. Edited by Andrzej Zieliński. Warszawa: C.H. Beck.

Franczak, Katarzyna. 2011. "Elektroniczne postępowanie upominawcze - zalety i wady dla stron postępowania". Przeglad Prawa Handlowego 7: 48-54.

Gwiazdomorski, Jan. 1955. "Podstawowe problemy przedawnienia". Nowe Prawo 1: 4-24.

Gwiazdomorski, Jan. 1955. "Przedawnienie czy zarzut przedawnienia?”. Nowe Prawo 4: 44-52. 
Gwiazdomorski, Jan. 1968. "Terminy zawite do dochodzenia roszczeń w kodeksie cywilnym”. Ruch Prawniczy, Ekonomiczny i Socjologiczny 3: 87-110.

Infor. 2017.http://www.infor.pl/prawo/w-sadzie/e-sad/320461,Nowelizacja-kodeksu-postepowaniacywilnego-zmiany-w-EPU.html [Accessed: 11 January 2017]

Jedliński, Adam. 2012. “Tytuł VI. Przedawnienie roszczeń”. In Kodeks cywilny. Komentarz. Część ogólna. Vol. I. 728-769. Edited by Andrzej Kidyba. Warszawa: Wolters Kluwer Polska.

Jędrzejewska, Maria. 2006. In Kodeks postępowania cywilnego. Komentarz. Vol. I. Edited by Tadeusz Ereciński. Warszawa: Wolters Kluwer Polska.

Kordasiewicz, Bogudar. 2008. „Rozdział XI. Problematyka dawności”. In System Prawa Prywatnego. Prawo cywilne - czesść ogólna. 563-698. Edited by Zbigniew Radwański. Warszawa: C.H. Beck.

Kuźmicka-Sulikowska, Joanna. 2015. Idea przedawnienia i jej realizacja w polskim kodeksie cywilnym. Wrocław: E-Wydawnictwo. Prawnicza i Ekonomiczna Biblioteka Cyfrowa.

Mańko, Rafał. 2015. "Relikty w kulturze prawnej. Uwagi metodologiczne na tle pozostałości epoki socjalizmu realnego w polskim prawie prywatnym". Przeglad Prawa i Administracji 102: 185-208.

Mańko, Rafał. 2016. "Demons of the Past? Legal Survivals of the Socialist Legal Tradition in Contemporary Polish Private Law". In Law and Critique in Central Europe. Questioning the Past, Resisting the Present. 66-89. Edited by Rafał Mańko, Cosmin Cercel, Adam Sulikowski. Oxford: Counterpress.

Mattei, Ugo. 1994. "Efficiency in Legal Transplants: An Essay in Comparative Law and Economics". International Review of Law and Economics 14: 3-19.

Miller, Jonathan. 2003. "A Typology of Legal Transplants: Using Sociology, Legal History and Argentine Examples to Explain the Transplant Process". The American Journal of Comparative Law 51: 845-868.

Pałdyna, Tomasz. 2012. Przedawnienie w polskim prawie cywilnym. Warszawa: Wolters Kluwer Polska.

Potejko, Patrycja. 2010. "Elektroniczne postępowanie upominawcze - fikcja wymiaru sprawiedliwości?". Monitor Prawniczy 1: 16-23.

Szer, Seweryn. 1950. Prawo cywilne - czesść ogólna. Warszawa: Państwowe Wydawnictwo Naukowe.

Szpak, Jagoda. 2011. "Kontrowersje wokół zagadnienia 'legal transplants”". Acta Erasmiana 1: $53-71$.

Szpunar, Adam. 1974. "Z problematyki przedawnienia roszczeń majątkowych”. Ruch Prawniczy, Ekonomiczny i Socjologiczny 3: 283-298.

Szpunar, Adam. 1980. "Zrzeczenie się korzystania z przedawnienia”. Palestra 4-5: 15-23.

Szpunar, Adam. 2002. "Uwagi o zrzeczeniu się zarzutu przedawnienia”. Rejent 10: 13-27.

Tchórzewski, Mariusz. Przemysław Telenga. 2010. Elektroniczne postępowanie upominawcze. Komentarz. Warszawa: Wolters Kluwer Polska.

Vis Legis. 2017. http://vislegis.biz/dochodzenie-roszczen-przedawnionych-w-epu/ [Accessed: 11 January 2017]

Wasilkowski, Jan. Ed. 1954. Projekt Kodeksu cywilnego Polskiej Rzeczypospolitej Ludowej. Warszawa: Wydawnictwo Prawnicze.

Watson, Alan. 1991. Legal Origins and Legal Change. London: The Hambledon Press.

Watson, Alan. 1993. Legal Transplants. An Approach to Comparative Law. Georgia: University of Georgia Press.

Watson, Alan. 1996. "Aspects of Reception of Law". American Journal of Comparative Law 44: $335-351$. 
Wilejczyk, Magdalena. 2014. “Nadużycie zarzutu przedawnienia przezdłużnika czy nieuwzględnienie upływu przedawnienia ze względu na szczególne okoliczności leżące po stronie wierzyciela - uwagi de lege ferenda". Monitor Prawniczy 5: 248-254.

Wilejczyk, Magdalena. 2014. Zagadnienia etyczne części ogólnej prawa cywilnego. Warszawa: C.H. Beck.

Wolter, Aleksander. 1953. Prawo cywilne - część ogólna. Warszawa: Państwowe Wydawnictwo Naukowe.

Wójcik, Sylwester. 1991. "Przedawnienie w prawie cywilnym po zmianie kodeksu cywilnego ustawą z 28 lipca 1990". Przegląd Sądowy 1-2: 25-36.

\section{Legal acts}

Act of 13 April 2018 amending the Act - Civil Code and some other acts (Dz.U. of 2018, item 1104). Act of 10 May 2013 amending the Code of Civil Procedure (Dz.U. 2013 item 654).

Act of 16 September 2011 amending the Code of Civil Procedure and some other acts (Dz.U. 233, item 1381).

Code of Civil Procedure of 17 November 1964 (Dz.U. 2016, item 1822 with amendments).

Polish Civil Code of 23 April 1964 (Dz.U. 2016, item 380 with amendments).

Act on General Provisions of the Civil Law of 18 July 1950 (Dz.U. 34, item 311).

Regulation of the President of the Republic of Poland of 27 October 1933 - Code of Obligations (Dz.U. 82, item 598 with amendments). 